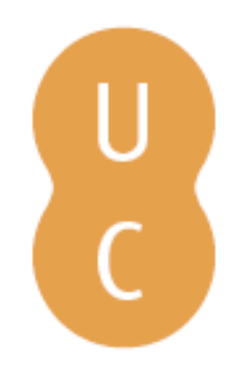

\title{
nommalina
}

\section{The effect of grass curing level on the propagation of grassland fires - an experimental study}

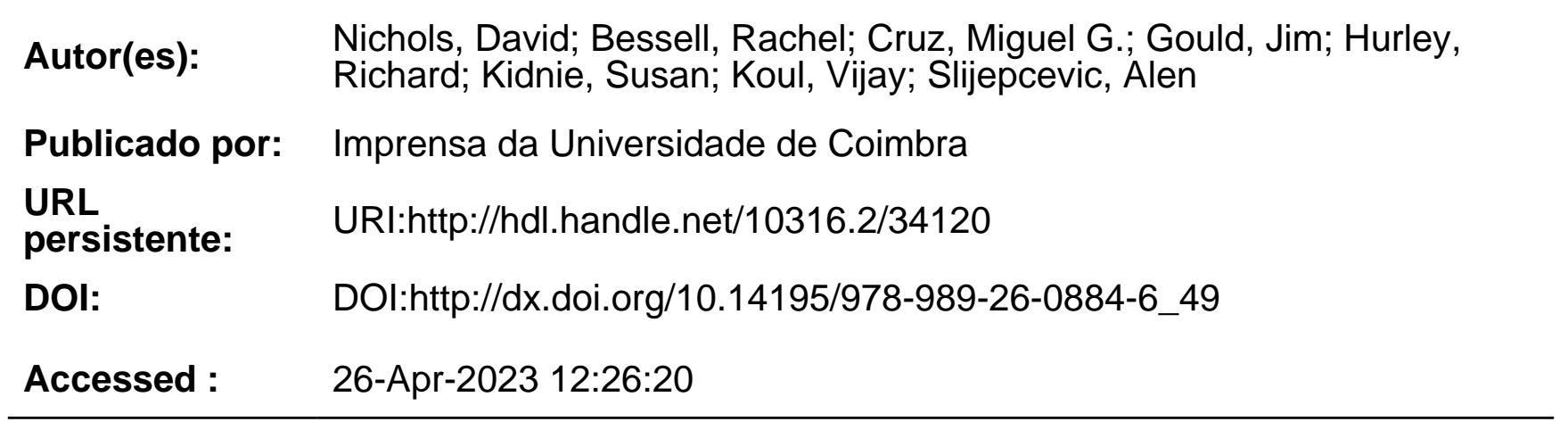

A navegação consulta e descarregamento dos títulos inseridos nas Bibliotecas Digitais UC Digitalis, UC Pombalina e UC Impactum, pressupõem a aceitação plena e sem reservas dos Termos e Condições de Uso destas Bibliotecas Digitais, disponíveis em https://digitalis.uc.pt/pt-pt/termos.

Conforme exposto nos referidos Termos e Condições de Uso, o descarregamento de títulos de acesso restrito requer uma licença válida de autorização devendo o utilizador aceder ao(s) documento(s) a partir de um endereço de IP da instituição detentora da supramencionada licença.

Ao utilizador é apenas permitido o descarregamento para uso pessoal, pelo que o emprego do(s) título(s) descarregado(s) para outro fim, designadamente comercial, carece de autorização do respetivo autor ou editor da obra.

Na medida em que todas as obras da UC Digitalis se encontram protegidas pelo Código do Direito de Autor e Direitos Conexos e demais legislação aplicável, toda a cópia, parcial ou total, deste documento, nos casos em que é legalmente admitida, deverá conter ou fazer-se acompanhar por este aviso.

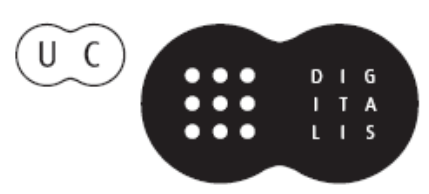




\section{ADVANCES IN}

Forest Fire

\section{RESEARCH}

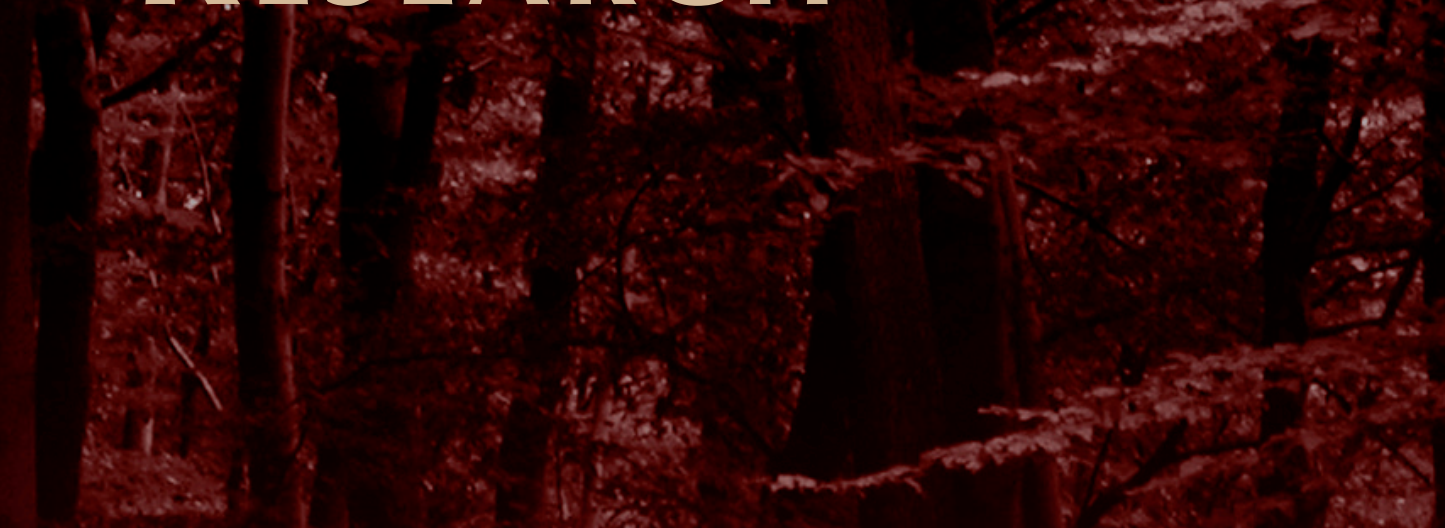

\section{DOMINGOS XAVIER VIEGAS}

\section{EDITOR}




\title{
The effect of grass curing level on the propagation of grassland fires - an experimental study
}

\author{
David Nichols ${ }^{\mathrm{a}}$, Rachel Bessella ${ }^{\mathrm{a}}$, Miguel G. Cruz ${ }^{\mathrm{b}}$, Jim Gould ${ }^{\mathrm{b}}$, Richard Hurley ${ }^{\mathrm{b}}$, Susan Kidnie ${ }^{\mathrm{a}}$, \\ Vijay Koul $^{\mathrm{a}}$, Alen Slijepcevic ${ }^{\mathrm{a}}$ \\ ${ }^{a}$ CFA, Fire and Emergency Management, PO Box 701, Mt Waverley, Victoria, Australia. \\ ${ }^{b}$ CSIRO Ecosystem Sciences, GPO Box 1700, Canberra, ACT 2601, Australia.
}

\begin{abstract}
Key to understanding fire propagation in grassland fuels is to know their annual growing cycle and the availability of biomass to be consumed by a fire. Curing is the progressive senescence and drying out of grass after flowering (annuals) or in response to drought (perennials) and is the key process transferring biomass from the live to the dead fuel component. Despite the relevance of fires in grasslands and savannah ecosystems in Australia and throughout the world, our understanding of (1) grass senescence effect on overall fuel moisture content and fuel availability, and (2) the degree of grass curing in fire behaviour, is still lacking. To investigate the effect of the curing process on grassland fire behaviour an experimental field study was conducted at two distinct locations in Victoria. Experimental burn plots size were 32 × $32 \mathrm{~m}$. Simultaneous burns were conducted with one plot being fully cured (100\%; control) and another being partially cured (treatment). Detailed measurements of fuel bed structure, weather variables (3D wind speed, air temperature, relative humidity and solar radiation) and fire behaviour (rate of spread, flame length, residence time and time-temperature profiles) were recorded on 52 experimental fires. The range of curing in the partially cured plots varied between approximately $35 \%$ and $90 \%$. The range of other fire environment parameters were: 2 -m wind speed: $5.4-20.5$ $\mathrm{km} / \mathrm{h}$; ambient air temperature: 16-33 C; relative humidity: 14-40 \%; Fire spread rates varied between 3.6 and $72 \mathrm{~m} / \mathrm{min}$. Preliminary analysis highlights include the observation of sustained fire spread with curing levels between $30-40 \%$ and the importance of the dead fuel component from the previous year growth to sustain propagation at these marginal conditions. The data collected is being used to reanalyze functional relationships currently used to express the effect of curing and live fuel moisture on the spread of grassland fires
\end{abstract}

Keywords: Grass curing, grass fire behaviour, fire danger ratings

\section{Introduction}

Key to understanding fire propagation in grassland fuels is to know their annual growing cycle and the availability of biomass to be consumed by a fire. Grassland curing is the progressive senescence and drying out of grass after flowering (annuals) or in response to drought (perennials) and is the key process transferring biomass from the live to the dead fuel component within the fuel complex. As senescing progresses, the fuel moisture content gradually decreases and the amount of dead material in the grassland increases. These changes have an important impact on fire behavior in grasslands. In Australia, where grasslands cover approximately $75 \%$ of the country, the degree of curing is used as an input into the calculation of grassfire spread and grassland fire danger ratings.

Despite the relevance of fires in grasslands and savannah ecosystems in Australia, and throughout the world, our understanding of (1) grass senescence effect on overall fuel moisture content and fuel availability, and (2) the degree of grass curing in fire behaviour, is still lacking. The ability to accurately assess the degree of curing is therefore important for fire agencies who predict fire danger throughout the fire season.

Grassland curing is a complex and dynamic process. The study examines the dynamics of grass curing levels through the grass life cycle and the relation to grassfire behaviour through the fire season. The 
objective is to provide better estimates of grass curing that could be used to predict rate of spread of grassfires.

\section{Methods}

Two distinct Victoria, Australia experimental field sites, located at Wangaratta South and Wendouree, with continuous grass cover were selected for studying grass curing dynamics and grassland fire behaviour during the 2013-14 fire season (October to February). The distinct predominant grass species present at each site resulted in distinctive fuel structures. One site consisted of coarser grass and higher fuel loads than the other site which was characterized by finer grass and lower fuel loads. The differences in each site had a significant effect on fire behaviour.

Experimental burn plots size were 32 × $32 \mathrm{~m}$. Simultaneous burns were conducted with one plot being fully cured (100\%; control) and another being partially cured (treatment). Detailed measurements of fuel bed structure, weather variables (3D wind speed, air temperature, relative humidity and solar radiation) and fire behaviour (rate of spread, flame length, residence time and time-temperature profiles) were recorded on 52 experimental fires. The range of curing in the partially cured plots varied between approximately $35 \%$ and $90 \%$. The range of other fire environment parameters were: $2-\mathrm{m}$ wind speed: 5.4 - $20.5 \mathrm{~km} / \mathrm{h}$; ambient air temperature: 16-33 C; relative humidity: 14-40 \%; Fire spread rates varied between 3.6 and $72 \mathrm{~m} / \mathrm{min}$.

\section{Results}

Preliminary analysis highlights include the observation of sustained fire spread with curing levels between $30-40 \%$ and the importance of the dead fuel component from the previous year growth to sustain propagation at these marginal conditions. The results indicate that the fire rates of spread of 40 to $60 \%$ cured can be as rapid as spread rates previously achieved by cured grasses of $60 \%$ and higher. The data collected is being used to reanalyze functional relationships currently used to express the effect of curing and live fuel moisture on the spread of grassland fires.

The results will feed into future grassland fire danger indices which contribute to the overall fire danger rating system. Accurate fire danger ratings allow fire agencies to plan for fire restrictions, resource allocation, total fire bans, fire behaviour modeling and community warnings during the fire season. 